\title{
Quality of Life in Patients with Neurodegenerative Diseases
}

\section{Patricia Batista and Anabela Pereira}

\author{
Aveiro University, Aveiro, Portugal
}

Corresponding author: Anabela Pereira, Associate Professor with Aggregation, Univeristy of Aveiro Education Campus, Universitário Santiago Aveiro, 3810-193, Portugal. Tel: +351 914250230; Fax: +351 234370 640; E-mail: anabelapereira@ua.pt

Received: Dec 11, 2015; Accepted: Feb 09, 2016; Published: Feb 15, 2016

\section{Abstract}

Neurodegenerative diseases are characterized by a progressive deterioration of brain function, with a significantly consequent decrease in the quality of life of patients and their families. Due to increasing life expectancy, the incidence of these diseases has increased over the years, and has been under research.

Objective: The aim of this paper is to systematically review the scientific literature about the evaluation of life' quality in patients with neurodegenerative diseases.

Methods: Reflective systematic literature review on Pubmed, MedLine and Scopus database with the keywords "quality of life of Patients" and "neurodegenerative diseases" was analyzed. It was analyzed in the period between 2000 and 2015. PRISMA criteria reporting of systematic reviews and meta-analyses were applied. The inclusion criteria were: usage of instrument to measure life' quality, presenting quantitative or qualitative results, and psychometric studies. It was excluded articles reviews outside the scope of the subject, theoretical articles and new therapies, diagnostic and palliative care.

Results: After applying the methodology, five scientific articles were included in the study. The measuring instruments were used the dimensions (physical, mental, social and environmental) were analyzed. It was analyzed the results obtained in the studies.

Conclusions: This literature review indicated that more research is needed to assess the impact of quality of life in patients with degenerative pathologies. The implications of these findings and potential directions for future research are discussed.

Keywords: Quality of life; Neurodegenerative diseases; Patients

\section{Introduction}

Neurodegenerative diseases result from the gradual degeneration and/or death of neurons (cells responsible for the nervous system functions). This degradation can affect body movement and brain function, causing dementia (progressive or chronic decline of cognitive function that affects memory, thinking, behaviour, language, calculation, learning and emotion capacity, and should never be associated with a normal aging process) [1].

These diseases are one of the most important medical and socio-economic problems of our time, affecting people of all ages. The causes of their appearance are not known; they can be different diseases: Alzheimer's disease (AD); Parkinson's disease (PD); Amyotrophic Lateral Sclerosis (ALS); Multiple Sclerosis (MS); Huntington's disease (HD); Machado-Joseph disease; Amyloid Polyneuropathy Family, being the best known, Alzheimer's and Parkinson's disease [2].

Neurodegenerative diseases have a major impact at professional, social and family level of patients and can lead to a complete inability to carry out any type of everyday activity. For example, patients may have: motors problems; breathing difficulties; cognitive problems or gradual memory loss (possibly affecting the memory of all that has been learned over a lifetime).

The major problem is that these disorders are normally detected late and restricting the efficacy of the treatment options.

Therefore, it is essential to support scientific research in this area, to accelerate the discovery of the causes and mechanisms of neurodegenerative diseases and develop preventive treatments, better suited to the symptoms of each disease. Similarly it is important to assess the impacts of diseases in dimensions of Health-Related Quality of Life (HRQoL), there have been few studies in this area [3].

The measures of HRQoL include physical, psychological and social dimensions [1-4]. Physical component summary (PCS) and mental component summary (MCS) are two measures of HRQoL (present on short form health survey). Other measures of HRQoL are Activities of daily living (ADL) and Instrumental activities of daily living (IADL), which are two measures of selfmaintenance and autonomy [1].

Few studies of quality of life in patients with neurodegenerative disease have been done. However, the World Health Organization (WHO) has developed crossculturally, two generic instruments to assess the quality of life (WHOQOL-100 and WHOQOL-BREF). Afterwards, due to studies of large scale that includes many factors or many situations where it is necessary an indicator of life' quality of 
rapid assessment, the EUROHISQOL 8 - index was developed (adapted of the WHOQOL-100 and WHOQOL-BREF).

In this article, it is also referenced to a new WHOQOL-DIS, which aims to complement the WHOQOL-BREF, assessing other dimensions [5]. Moreover, it will be mentioned the HRQoL which includes physical, psychological and social dimensions (Wilson and Cleary Model) [1].

It should be noted that currently there is no systematic literature review that provides an insight into the quality of life in patients with neurodegenerative disease by focusing on psychosocial factors. In addition, systematic studies on this subject are reduced. Thus, the aim of this study is to provide an overview of the scientific evidence produced on that topic or subject.

\section{Methods}

We conducted a study of reflective systematic literature review. Between 2000 and 2015, we identified scientific published papers in international journals, using a database research in digital format, MedLine and PubMed, and in a second phase to Scopus. The descriptors used in the research were: ["quality of life and neurodegenerative diseases"]. Later, because of the high number of matches (5099 publications), the research was refined to ["quality of life" and "neurodegenerative diseases"], obtaining 262 publications; then it was made a new research with the keywords ["quality of life of patients" and "neurodegenerative diseases"] (162 abstracts published). The study was restricted to published English articles.

The research with the final descriptors ["quality of life of patients" and "neurodegenerative diseases"] resulted in 162 publications in PubMed database, 16 publications in MedLine and 16 publications in Scopus. It was analyzed 162 publications obtained in the PubMed database, form excluded 151 publications: 88 publications were outside the scope of the study, they were related to other pathologies or out of context themes; 21 were related to the issue of gene and/or cell therapies, pharmaceutical therapy; 18 reported individual factors affecting the quality of life of patients (such as, sleep, depression, olfactory loss, urinary dysfunction, gait disturbances, motor complications, dysphagia and disorientation); 6 related to exhaustive description of some neurodegenerative diseases; 5 quoted palliative care; 7 stated the question of the role of caregivers, care networks and care; 4 referred to animal models tests; 2 publications, one reported a pilot study and another diagnostic models.

The structured research resulted in 11 publications under the theme that was intended to assess these only 7 articles were available, and 2 articles were excluded because upon examination it was found that an article concerned about psychometric study to measure the quality of life in patients with tremor and intended to evaluate a range, and in another article the quality of life was approached after in patients with Parkinson's surgery. The inclusion and exclusion criteria of the studies are described in Table $\mathbf{1}$ and Figure $\mathbf{1}$
PRISMA criteria for preferred reporting items for systematic reviews and meta-analyses (Prisma) ${ }^{\underline{a}}$ were applied. The collected information was compiled and analysed regarding the year of publication, authors, sample, and country, type of study/methodology, results and aim.

The cataloguing and identification of repeated references were made through the computer program EndNote bibliographic referencing.

\section{Analysis of Results and Discussion}

For a better understanding of the systematic literature review, the analyzed studies were compiled in a summary table (Table 2). In this table, there were several items: year of publication/authors, sample, country, methodology, instruments, results and aims.

Five complete articles which met the inclusion criteria were analyzed.

A total of 1872 adults from four different countries (United States, Canada, Croatia and Spain) were also analyzed. Different dimensions to evaluate the quality of life were included in the investigation, such as, social, psychological and environmental, as well as individual's physical and mental components.

Similarly, many instruments were used to measure different dimensions in the study.

A cross-sectional study methodology was clearly distinguished; the longitudinal methodology was only present in one study. One article referred a systematic review and another psychometric study of a scale validation.

The current review revealed few studies about this issue which is so relevant today, "Quality of life in patients with neurodegenerative disease."

Neurodegenerative diseases are characterized by a progressive deterioration of brain function, consequently, with a significant decrease in patients and their family's quality of life [5]. These diseases have a physical, mental and social impact, and this impact extends far beyond the obvious characteristic of the disease' symptoms [3].

The concept quality of life is variously used to indicate health and functional status, perceived health status, subjective health, health perception, symptoms, satisfaction, cognition, functional disability, disorder and well-being [4]. Often in clinical studies these terms are interchangeably used, although, it is evident that they are different concepts. It is crucial to emphasize the importance of differentiating health status and quality of life.

Quality of life presents a wide range of dimensions in human experience, ranging from those associated with the basic necessities of life, to the realization of feelings and satisfaction; even including physical, psychological and social dimensions [1-3].

In literature, the most studied neurodegenerative diseases were Parkinson's, Alzheimer's disease and Multiple Sclerosis. 
In general, these diseases have typical symptoms, such as, weakness, fatigue, motor impairment, ataxia, dysphagia, urinary complications, sensory loss, depression, cognitive decline, sleep disorders, among others [8-16]. These symptoms are potential contributors to lower health-related quality of life.

Table 1 Criteria for inclusion and exclusion in a research "Quality in life of patients with neurodegenerative diseases"

\begin{tabular}{|l|l|}
\hline Inclusion Criteria & Exclusion Criteria \\
\hline Use of measuring Quality of Life instruments & No use of measuring Quality of Life instruments \\
\hline Presentation/analysing quantitative/qualitative data & No presentation/analyzing quantitative/qualitative data \\
\hline Psychometric studies of psychometric validation of scale/instruments & \\
\hline
\end{tabular}

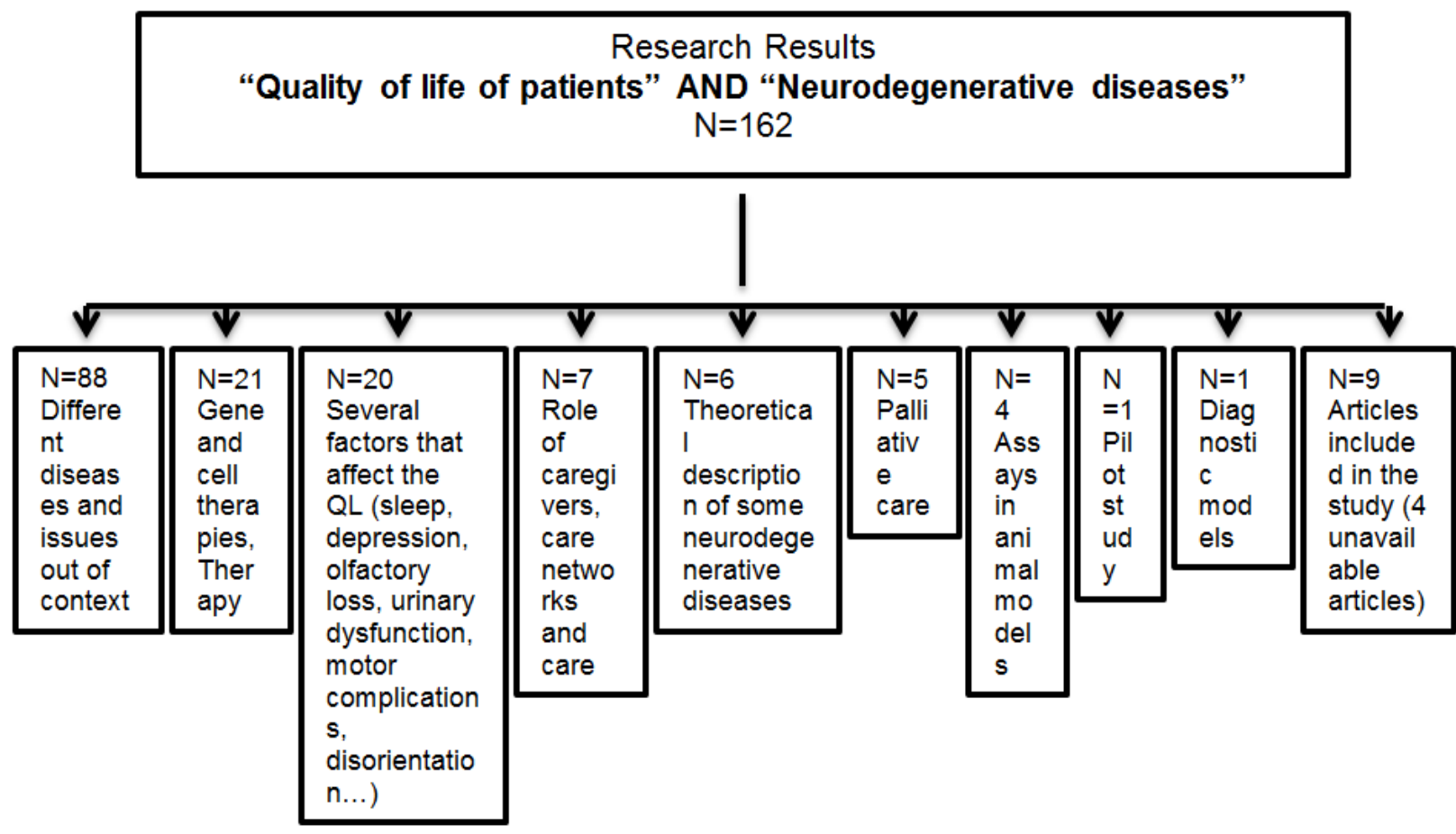

Figure 1 Flowchart - applying the inclusion and exclusion criteria in research

In this literature review, we analyzed the physical component (PCS) and mental (MCS) of patients with Parkinson's compared to patients with neurodegenerative dementia [1]. Several predictors of physical and mental components were found [1]. Associations with visual attention/memory functions, visuospatial and executive have been established and cognitive domains are apparently related to life' quality [7].

The impairment of these areas affects negatively the activities of daily living ( $A D L$ ) in patients with Parkinson's disease, not only the basic physical activities, with instrumental activities of daily living (IADL). Similarly, the realization of labour is also a compromised activity. It was found that the value of life in patients with Multiple Sclerosis influences a lot the quality of life, affecting the labour activity, labour productivity and increasing the use of health resources. It should also be noted that the reduction in daily activities are likely to negatively affect the perception of the same; and can negatively affect many other areas, such as, self-perception of cognitive status, emotional well-being, communication skills, and social stigma.

In general, data suggest that patients with Parkinson's disease and/or Multiple Sclerosis, present lower levels of HRQoL in emotional, physical and social terms than the general population $[1,2,5]$. The presents studies evaluated the association of HRQoL in patients with Parkinson's and Multiple Sclerosis disease, such as, depressive symptoms (high level of depression) and also (although less prominent and/or less consistently) deficiencies, high motor difficulties, longer disease and risk behaviors (smoking, alcohol) [5-7].

For the study and to evaluate these disorders and their influence on quality of life it is important to use measuring instruments, its development and validation. The HRQoL measure, however, it is not easy, because it is not directly observable and is often assessed by questionnaires about daily activity, functional capacity, cognitive performance and/or selfreports (selection of instruments based on evaluations made 
by patients, may have implications for the accuracy of the information, when faced with clinical information) [4,17].

The most commonly used instruments are the generic (include individual indicators, health profiles and utilities measures) are suitable to be used in different populations and diseases, have advantages of wide applicability in diagnostics, and consequently have a decision making impact, as well as, in clinical practice and research. Many have been considered valid and reliable, increasing their usefulness in clinical scope. Sometimes, it is used very specific instruments, targeted for a specific disease. These measurements were repeated in a number of different neurodegenerative diseases, but are often criticized due to the lack of specificity and insensitivity to change over time [2]. Both measures (generic and specific) are typically used to help assess the effectiveness of the trial and intervention research, however, there may still be other approach to the question, when measuring the quality of life focuses on state aspects of health, self-perception and perception of others.

Following the importance of instruments to assess quality of life in patients with neurodegenerative diseases, we found an article that analyses the psychometric properties of the WHOQOL-BREF and the new WHOQOL-DIS (for people with physical disabilities associated with neurodegenerative diseases). It was also objective of the study, validate these two instruments and their relationship to quality of life through the analysis of Hospital Anxiety and Depression Scale - Depression (HADS-D), Fatigue Assessment Scale (FAS) and Satisfaction With Life (SWL), Multiple Sclerosis Impact Scale (MSIS-29), Parkinson's Disease Questionnaire (PDQ-39) [5,7].

WHOQOL-BREF is a generic QL questionnaire, with items grouped into four domains (physical, psychological, social and environmental) and two global items related to overall $Q \mathrm{~L}$ and satisfaction with health, which reflects social relations and the environment, these areas are often overlooked in other questionnaires. WHOQOL-DIS assesses the overall disability impact, focuses mainly on psychosocial aspects relevant to adults with disabilities and captures the impact of disability in people's lives [5]. Thus, these instruments can provide useful information along the continuum of care for people with neurodegenerative disease, from early diagnosis to more severe states, ambulatory and hospital services, health and the level of social assistance. Therefore, these instruments appear to be promising tools to monitor QL changes [4].

\section{Summary of methodological limitations}

The methodology selected for inclusion and exclusion of these studies, always limits the results obtained, leaving out many valid data studies, especially in this emerging area such as "quality of life in patients with neurodegenerative diseases", so that they can be excluded relevant factors to the understanding of the subject.

The lack of publications in this area, also conditioned this selection, analysis and generalization of the results. They approached to some assessment of the measure of quality of life instruments, however, not consistent with a single instrument, conditioned evaluation and a more overview comprehensive of different studies. The use of a single measuring instrument, would have allowed an easier and a more correct comparison of the identified variables and the nature of the instrument would have allowed to cover a greater number of factors.

We found limitations in the analyzed articles: not representative sample of the population [1], the relevance of self-report (which can condition the individual and clinical characteristics) $[1,4,6]$, the cross-sectional design of the study $[1,6]$, the use of non-specific resources for pathologies [6], the data generalization to clinical observations [7].

\section{Implications for Practice}

Neurodegenerative diseases are, undoubtedly, a growing problem in health sciences, due to increased life expectancy and unhealthy life. Although the mechanisms of these diseases are still far from being clarified, several studies have been made in this direction, to promote and learn to deal with these conditions.

The literature review aimed to present the information obtained about "Quality of life in patients with neurodegenerative disease". Despite the scarce publications found, this study aimed to discover what has been done and emphasize the importance to develop future research.

The current review suggest, new studies about measuring instruments to quality life in patients with neurodegenerative diseases, build (more specific items, for each pathology), validate and apply.

More longitudinal studies are important, for example, a gender differences study. Furthermore, it is important to extend these studies to other countries, including the Portuguese-Brazilian community.

Another underlying implication of this study is related to a great ambiguity of terms, and in future studies should be interesting to standardize anthologies descriptors factors associated with quality of life/neurodegenerative diseases.

\section{Conclusion}

Neurodegenerative diseases are a growing worldwide problem, due to the aging population and to the risk behaviour that it shows. Improving the quality of life of individuals is as important as investing in prevention and cure of diseases.

This study sought to address the issue and to find that there is still much to do. Also, it intends to draw attention to the importance of recognizing and documenting the subjective impact of the disease. Individual, biological and environmental factors were mentioned to be directly related to the quality of life in patients with neurodegenerative diseases. The knowledge of these factors can be useful in reducing emotional, psychological and social charge, promoting the well-being and in improving the quality of life of these patients. 
Thus, more research is needed, more interventions, and more tools are needed for assessing the impact of quality of life in degenerative pathologies, improving the quality of life of these patients.

\section{Conflict of Interest}

Nothing to declare.

Table 2 Summary of information from five relevant articles met our inclusion criteria in the study of "Quality of life in patients with neurodegenerative diseases"

\begin{tabular}{|c|c|c|c|c|c|c|c|}
\hline $\begin{array}{l}\text { Authorl } \\
\text { Year }\end{array}$ & Sample & $\begin{array}{l}\text { Countr } \\
y\end{array}$ & Methodology & Instruments & $\begin{array}{l}\text { Dimension } \\
\text { s } \\
\text { evaluated }\end{array}$ & Results & Aim \\
\hline $\begin{array}{l}\text { Chekani } \\
\text { et al., } \\
2015 \text { [1] }\end{array}$ & $\begin{array}{l}\mathrm{N}=796 \text { adults with } \\
\text { Neurodegenerative } \\
\text { Diseases } \\
\text { (International } \\
\text { Classification of } \\
\text { Diseases } \\
(\text { ICD9CM)) - } \\
\text { Database } \\
2002-2011 \text { Medical } \\
\text { Expenditure Panel } \\
\text { Survey (MEPS) }\end{array}$ & $\begin{array}{l}\text { United } \\
\text { States }\end{array}$ & $\begin{array}{l}\text { Longitudinal, } \\
\text { Retrospective } \\
\text { cross-sectional } \\
\text { design to } \\
\text { examine HRQoL } \\
\text { among patients } \\
\text { with PD and } \\
\text { neurodegenerati } \\
\text { ve dementia }\end{array}$ & $\begin{array}{l}\text { HRQoL } \\
\text { (include } \\
\text { physical, } \\
\text { psychological } \\
\text { and social } \\
\text { dimension) } \\
\text { (Wilson and } \\
\text { Cleary Model) }\end{array}$ & $\begin{array}{l}\text { PCS, } \\
\text { MCS, } \\
\text { ADL } \\
\text { IADL }\end{array}$ & $\begin{array}{l}\text { Average age } 74 \text { years; Most } \\
\text { patients with PD were male, } \\
\text { and most neurodegenerative } \\
\text { dementia patients were female. } \\
\text { Patients with PD showed a } \\
\text { lower PCS analysis and were } \\
\text { less likely to seek help for IADL } \\
\text { MCS were not found different } \\
\text { results among patients. } \\
\text { ADL, there were no significant } \\
\text { differences between patients } \\
\text { with PD and neurodegenerative } \\
\text { dementia. } \\
\text { Individual, biological and } \\
\text { environmental factors have } \\
\text { been associated with quality of } \\
\text { life in patients with PD and } \\
\text { neurodegenerative dementia. }\end{array}$ & $\begin{array}{l}\text { (1) assess quality of } \\
\text { health of life in } \\
\text { Parkinson's disease } \\
\text { and } \\
\text { neurodegenerative } \\
\text { dementia, (2) identify } \\
\text { predictors of PCS } \\
\text { and MCS in patients } \\
\text { with } \\
\text { neurodegenerative } \\
\text { diseases, and (3) to } \\
\text { identify predictors of } \\
\text { ADL and IADL in } \\
\text { patients with } \\
\text { neurodegenerative } \\
\text { diseases. }\end{array}$ \\
\hline $\begin{array}{l}\text { Gupta } \\
\text { et al., } \\
2014 \text { [6] }\end{array}$ & $\begin{array}{l}N=536 \text { with } M S \\
(N=74 \text { control })\end{array}$ & $\begin{array}{l}\text { United } \\
\text { States }\end{array}$ & $\begin{array}{l}\text { Cross } \\
\text { study analysed } \\
\text { cross-sectional } \\
\text { data from the } \\
2009 \text { US } \\
\text { National Health } \\
\text { and Wellness } \\
\text { Survey (NHWS), }\end{array}$ & $\begin{array}{l}\text { HRQoL } \\
\text { (include } \\
\text { physical, } \\
\text { psychological } \\
\text { and social } \\
\text { dimension) } \\
\text { (Wilson and } \\
\text { Cleary Model) }\end{array}$ & $\begin{array}{l}\text { PCS } \\
\text { MCS }\end{array}$ & $\begin{array}{l}\text { The significant differences } \\
\text { between MS and controls - MS } \\
\text { can interfere too much with } \\
\text { QOL, work productivity and } \\
\text { increase the use of health } \\
\text { resources. } \\
\text { Increased severity of MS may } \\
\text { be accompanied by a greater } \\
\text { involvement of labour activity, } \\
\text { lower productivity at work and } \\
\text { increased use of health care. } \\
\text { Transition between degrees of } \\
\text { severity of the disease may not } \\
\text { be linear and increasing the } \\
\text { severity of MS is associated } \\
\text { with worse health outcomes. }\end{array}$ & $\begin{array}{l}\text { Compare the quality } \\
\text { of life of health, } \\
\text { labour productivity, } \\
\text { commitment, activity } \\
\text { and resource } \\
\text { utilization among } \\
\text { patients with MS and } \\
\text { controls, as well as } \\
\text { through MS patients } \\
\text { with different self- } \\
\text { reported with severity } \\
\text { disease. }\end{array}$ \\
\hline $\begin{array}{l}\text { Lucas- } \\
\text { Carrasc } \\
\text { o et al., } \\
2011 \text { [5] }\end{array}$ & $\begin{array}{l}\mathrm{N}=149(84 \text { with } \\
\mathrm{MS} \text { and } 65 \text { with } \mathrm{PD}\end{array}$ & Spain & $\begin{array}{l}\text { Psychometric } \\
\text { properties } \\
\text { WHOQOL-BREF } \\
\text { and WHOQOL- } \\
\text { DIS }\end{array}$ & $\begin{array}{l}\text { WHOQOL- } \\
\text { BREF; } \\
\text { WHOQOL- } \\
\text { DIS; } \\
\text { PDQ-39; } \\
\text { MSIS-29; } \\
\text { FAS; } \\
\text { HADS-D; } \\
\text { SWL Scale }\end{array}$ & $\begin{array}{l}\text { psychosoci } \\
\text { al, social } \\
\text { and } \\
\text { environmen } \\
\text { tal } \\
\text { dimension }\end{array}$ & $\begin{array}{l}\text { WHOQOL-BREF and } \\
\text { WHOQOL-DIS - acceptable } \\
\text { levels of acceptability, internal } \\
\text { consistency, and validity (high } \\
\text { correlations of the WHOQOL- } \\
\text { BREF and WHOQOL-DIS with } \\
\text { HADSD scales, DO, SWL, } \\
\text { MSIS-29 and PDQ-39). There } \\
\text { is the self-perception and self- } \\
\text { reporting, with significant } \\
\text { differences in three domains } \\
\text { (physical, psychological and } \\
\text { environmental). Relative } \\
\text { deficiency in life, participants } \\
\text { with mild to moderate disease } \\
\text { had improved quality of life in } \\
\text { all areas compared to serious } \\
\text { illness. } \\
\text { WHOQOL-BREF - two domains } \\
\text { of quality of life (social relations } \\
\text { and environment) are often } \\
\text { omitted in other measures. } \\
\text { WHOQOL- DIS - psychosocial } \\
\text { aspects relevant to adults with } \\
\text { disabilities and captures the } \\
\text { impact of disability on a } \\
\text { person's life. }\end{array}$ & $\begin{array}{l}\text { Using the WHOQOL- } \\
\text { BREF and } \\
\text { WHOQOL-DIS to } \\
\text { measure quality of } \\
\text { life in people with } \\
\text { physical disabilities } \\
\text { caused by } \\
\text { neurodegenerative } \\
\text { disorders. }\end{array}$ \\
\hline
\end{tabular}




\begin{tabular}{|c|c|c|c|c|c|c|c|}
\hline $\begin{array}{l}\text { Klepac } \\
\text { et al., } \\
2008 \text { [7] }\end{array}$ & $\mathrm{N}=124$ with $\mathrm{PD}$ & Croatia & Cross clinical & $\begin{array}{l}\text { PDQ-39 to } \\
\text { evaluate } \\
\text { HRQoL and } \\
\text { Beck's } \\
\text { Depression } \\
\text { Inventory } \\
\text { (BDI) to } \\
\text { quantify } \\
\text { depression }\end{array}$ & $\begin{array}{l}\text { Cognitive } \\
\text { performanc } \\
\mathrm{e}\end{array}$ & $\begin{array}{l}\text { Preliminary Assessment } \\
\text { (univariate analysis) indicated } \\
\text { visual attention / memory, } \\
\text { visuospatial and executive } \\
\text { functions such as cognitive } \\
\text { domains apparently related to } \\
\text { HRQL. } \\
\text { The results strongly suggest a } \\
\text { better visual attention / memory } \\
\text { and better visuospatial and } \\
\text { executive functioning, are } \\
\text { independently associated with } \\
\text { better HRQOL. }\end{array}$ & $\begin{array}{l}\text { Explore the } \\
\text { relationship between } \\
\text { cognitive } \\
\text { performance and } \\
\text { HRQOL in non- } \\
\text { demented patients } \\
\text { with Parkinson's } \\
\text { disease. }\end{array}$ \\
\hline $\begin{array}{l}\text { Kern e } \\
\text { Brown, } \\
2004 \text { [4] }\end{array}$ & $\begin{array}{l}\mathrm{N}= \\
\text { (quantitative } \\
\text { studies Quality of } \\
\text { Life and Health } \\
\text { Status) }\end{array}$ & Canada & $\begin{array}{l}\text { Systematic } \\
\text { review }\end{array}$ & & $\begin{array}{l}\text { Quality of } \\
\text { Life, } \\
\text { Health } \\
\text { Physics; } \\
\text { Mental } \\
\text { health; } \\
\text { Health }\end{array}$ & $\begin{array}{l}\text { Lower mental health and quality } \\
\text { of life in patients with chronic } \\
\text { progressive neurodegenerative } \\
\text { disease (CPND). } \\
\text { Differential receptivity of mental } \\
\text { health appears to be higher in } \\
\text { multiple sclerosis. } \\
\text { Apparent lack of difference in } \\
\text { physical mental-health health } \\
\text { responses in ALS, the } \\
\text { responsiveness of } \\
\text { parkinsonism may reflect the } \\
\text { small number of paired } \\
\text { comparisons or the negative } \\
\text { influence of cognitive } \\
\text { dysfunction in the development } \\
\text { or change of response } \\
\text { assessment. al. al an } \\
\text { Response change is also an } \\
\text { active response in the cognitive } \\
\text { process that is limited in } \\
\text { degenerative neurological } \\
\text { conditions associated with } \\
\text { dementia. }\end{array}$ & $\begin{array}{l}\text { Review the case, } \\
\text { adaptation disease } \\
\text { could be measured in } \\
\text { progressive chronic } \\
\text { neurological } \\
\text { diseases (CPND) by } \\
\text { means of longitudinal } \\
\text { comparisons paired } \\
\text { with quality of life } \\
\text { (QoL) and health } \\
\text { status (HS) and } \\
\text { mental health (MH) } \\
\text { and physical health } \\
\text { (PH) domains of } \\
\text { quality of life } \\
\text { instruments. }\end{array}$ \\
\hline
\end{tabular}

\section{References}

1. Chekani F, Bali V, Aparasu RR (2015) Quality of life of patients with Parkinson's disease and neurodegenerative dementia: A nationally representative study. Res Social Adm Pharm S: 1551-7411.

2. Paulsen JS, Nance M, Kim J, Carlozzi NE, Panegyres PK, et al. (2013) A review of quality of life after predictive testing for and earlier identification of neurodegenerative diseases. Progress in Neurobiology 110: 2-28.

3. Welsh MD (2001) Measurement of quality of life in neurodegenerative disorders. Curr Neurol Neurosci Rep 1: 346-9.

4. Kern RZ, Brown AD (2004) Disease adaptation may have decreased quality-of-life responsiveness in patients with chronic progressive neurological disorders. J Clin Epidemiol 57: 1033-1039.

5. Lucas-Carrasco R, Pascual-Sedano B, Galán I, Kulisevsky J, SastreGarriga J, et al. (2011) Using the WHOQOL-DIS to measure quality of life in persons with physical disabilities caused by neurodegenerative disorders. Neurodegener Dis 8: 178-186.

6. Gupta S, Goren A, Phillips AL, Dangond F, Stewart M (2014) Selfreported severity among patients with multiple sclerosis in the USA and its association with health outcomes. Mult Scler Relat Disord 3: 78-88.

7. Klepac N, Trkulja V, Relja M, Babić T (2008) Is quality of life in non-demented Parkinson's disease patients related to cognitive performance? A clinic-based cross-sectional study. Eur J Neurol 15: $128-133$

8. Herrera AJ, Espinosa-Oliva AM, Oliva-Martin MJ, Carrillo-Jimenez A, Venero JL, et al. (2015) Collateral Damage: Contribution of Peripheral Inflammation to Neurodegenerative Diseases. Curr Top Med Chem 15: 2193-2210.

9. Martínez-Martín P, Jiménez-Jiménez FJ, García EC, AlonsoNavarro H, Rubio L, et al. (2010) Most of the Quality of Life in Essential Tremor Questionnaire (QUEST) psychometric properties resulted in satisfactory values. J Clin Epidemiol 63: 767-773.

10. Lengerer S, Kipping J, Rommel N, Weiss D, Breit S, et al. (2012) Deep-brain-stimulation does not impair deglutition in Parkinson's disease. Parkinsonism Relat Disord 18: 847-853.

11. Winge $K$ (2015) Lower urinary tract dysfunction in patients with parkinsonism and other neurodegenerative disorders. Handb Clin Neurol 130: 335-356.

12. Hüttenbrink KB, Hummel T, Berg D, Gasser T, Hähner A (2013) Olfactory dysfunction: common in later life and early warning of neurodegenerative disease. Dtsch Arztebl Int 110: 1-7.

13. Baquero M, Martín N (2015) Depressive symptoms in neurodegenerative diseases. World J Clin Cases 3: 682-693.

14. Suzuki K, Miyamoto M, Miyamoto T, Iwanami M, Sakuta $H$, et al. (2012) Sleep disturbances in patients with Parkinson disease. Brain Nerve 64: 342-355.

15. Schrempf W, Brandt MD, Storch A, Reichmann H (2014) Sleep disorders in Parkinson's disease. J Parkinsons Dis 4: 211-221. 
16. Porter VR, Buxton WG, Avidan AY (2015) Sleep, cognition and dementia. Curr Psychiatry Rep 17: 97.
17. Jin Z, Liu M, Albert S, Ying Z (2006) Analysis of longitudinal health-related quality of life data with terminal events. Lifetime Data Anal 12: 169-190. 